\title{
Corporate social responsibility, profits and welfare with managerial firms
}

\author{
Luciano Fanti ${ }^{1} \cdot$ Domenico Buccella ${ }^{2}$
}

Received: 20 September 2015/Accepted: 23 March 2017/Published online: 5 April 2017

(C) The Author(s) 2017. This article is an open access publication

\begin{abstract}
This paper analyses the equilibrium outcomes in a duopoly market where firms follow corporate social responsibility (CSR) behaviours under managerial delegation. It is shown that in the subgame perfect Nash equilibrium of the game, both firms emerge as CSR-type, and the firms' profitability (resp. the welfare of consumers and society) are beneficiated (resp. harmed) by the CSR behaviour. This result is in sharp contrast with the conventional result (established under nonmanagerial firms) that the higher the CSR sensitivity to consumer surplus, the lower (resp. higher) the firms' profitability (resp. the consumer surplus and social welfare).
\end{abstract}

Keywords CSR · Managerial delegation · Duopoly $\cdot$ Profitability $\cdot$ Social welfare

JEL Classification D21 $\cdot$ L13 $\cdot$ L14 $\cdot$ M14

\section{Introduction}

In the recent years, the debate on firms' social responsibility has been raised more frequently also in the academic literature (e.g. Baron 2001, 2009; Jensen 2001; Goering 2007, 2008; Lambertini and Tampieri 2010; Benabou and Tirole 2010).

Domenico Buccella

buccella@kozminski.edu.pl

Luciano Fanti

lfanti@ec.unipi.it

1 Department of Economics and Management, University of Pisa, Via Cosimo Ridolfi, 10, 56124 Pisa, PI, Italy

2 Department of Economics, Kozminski University, Jagiellońska Street, 57/59 - 03301, Warsaw, Poland 
According to a well-known classification (Garriga and Melè 2004), the most relevant corporate social responsibility (henceforth, CSR) theories and related approaches are focused on one of the following aspects of social reality: economics, politics, social integration and ethics. Needless to say, the realm of economics is that concerning our approach, according to which corporation is an instrument ${ }^{1}$ for wealth creation whose sole social responsibility is the maximisation of shareholder value (for instance measured by the share price) which in turn, in the standard industrial organisation literature, leads to a short-term profits orientation. In such a context (where the shareholder value maximisation is the supreme reference for corporate decision-making, as in the basic Cournot model), there is no room for CSR (unless the latter directly or indirectly positively affects economic costs of firms). ${ }^{2}$

In the context of the basic Cournot model, the conventional wisdom as regards the welfare effects of the introduction of social concerns in the firms' behaviour argues that, in general, increasing social concern or responsibility of the firms is necessarily welfare improving. For example, this is the view prevailing in the European Union and between most scholars. ${ }^{3}$ On the other hand, profits are expected to reduce adopting CSR behaviour, although recently it has been argued that shareholder value maximisation is not incompatible with satisfying certain interests of people with a stake in the firm (stakeholders) provided that it is specified a long-term value maximisation rather than the short-run profit maximisation, such as the "enlightened value maximisation" proposed by Jensen (2000).

In this paper, we show that this conventional wisdom is not necessarily true, since the effects of adopting CSR behaviours on profits and social welfare may be also dependent upon (1) the interaction between the strategic market context in which the socially concerned firms operate; and (2) the choice of hiring or not a manager for delegating the strategic choices.

\footnotetext{
1 In fact Garriga and Melè (2004) denote as "instrumental theories" those belonging to this economic approach, whose the most well-known representative is the Nobel prize Friedman (1970) stating that "the only one responsibility of business towards society is the maximisation of profits to the shareholders within the legal framework and the ethical custom of the country".
}

\begin{abstract}
2 As known in this standard literature-and also in the present model-firm's costs are not at all dependent of the level of engagement in social activities by the same firms. Of course if this was not true, then any investment in social demands that would reduce firm's costs would also produce an increase of the shareholder value, as in the case clearly analysed by the same Friedman (1970) (quoted in Garriga and Melè 2004, p. 53): "It will be in the long run interest of a corporation that is a major employer in a small community to devote resources to providing amenities to that community or to improving its government. That makes it easier to attract desirable employees, it may reduce the wage bill or lessen losses from pilferage and sabotage or have other worthwhile effects". Moreover the literature has pointed out that CSR could have the potential to ameliorate firms' profitability also through other various channels: for instance by reducing turnover rates and operating costs, by enhancing efficiency, by attracting better and/ or more loyal and motivated employees (e.g. Chong and Tan 2010). However, in the absence of the above-mentioned motives, the expected result is that the firm's profit is always reduced by a CSR.

3 For instance, the content of the European Union Commission's Green Paper (2001), "Promoting a European framework for corporate social responsibility", evidently shows the belief that social concern is welfare improving. Frank (2003) argues that social concern adds to the social welfare by enhancing the "common good".
\end{abstract}


For showing this, we adopt the Cournot duopoly model with managers following the managerial delegation literature (e.g. Vickers 1985; Fershtman and Judd 1987). As widely observed in real world, CSR rules are often adopted by large corporations where ownership and control are separated. In fact, according to the KPMG Survey of Corporate responsibility reporting (2013), 93\% among the world's largest 250 companies records CRS activities. Forbes (2014) reports the results of the Reputation Institute (2014) CSR survey, which confirms that the world's top ten companies with the best CSR reputations are widely known large, managerial companies. $^{4}$

In particular, we aim to answer the following research questions. First, which effect has firms' social responsibility on quantity, price, consumer surplus and total welfare? Second, as to firms, could it pay off to be socially responsible? Third, as to consumers and society, is the adoption of socially responsible rules by firms really welfare improving?

We assume that the shareholders may instruct their manager to pursue social objectives (represented, as usual in the literature, by an interest for the welfare of consumers); however, as in the standard profit-seeking world, the choice of the manager's incentive contract by shareholders aims to maximise profits. This could mean that the stakeholder participation in governance is in hiring managers selecting the optimal output level according to the stakeholder interests; nevertheless, it does not extend down to stipulate manager's contracts.

The current paper contributes to the literature by providing with a description in "strategic" terms of the multi-various phenomenon of the CSR. Several scholars have focused their attention on the reasons that lead companies to embrace CSR behaviours (Baron 2001, 2009; García-Gallego and Georgantzís 2009; Benabou and Tirole 2010; Reinhardt and Stavins 2010; Lambertini and Tampieri 2010). Baron (2001) put emphasis on the fact that companies may strategically follow CSR rules because guided by their selfishness. In fact, "social activists" such as non-governmental organizations (NGOs) can directly exercise "social pressure" on companies to adopt "responsible behaviours" through threats (boycott, negative propaganda) or rewards (endorsements). As a consequence, CSR can simply be a keen response to that pressure. On the other hand, Benabou and Tirole's (2010) standpoint is that several interacting motivations (ranging from pure altruism to material motivation, social and self-esteem concerns) lead firms to pro-social CSR behaviour. Moreover, as Reinhardt and Stavins (2010) argue, if there are customers willing to pay for ethical goods, and this can be profitable, CSR arises as a strategy like any other form of product differentiation: according to the basic economics, the opportunity emerges because of the presence of asymmetric information, economies of scale, intellectual-property protection and the successful defence of the ensuing niche against imitators.

Nonetheless, the previous contributions do not deal with the issue of managerial delegation with firms of CSR-type, a subject which has been scanty studied in the

\footnotetext{
4 According to the Reputation Institute (2014), the first ten place ranking is the following: (1) Google; (2) Microsoft; (3) The Walt Disney Company; (4) BMW; (5) Apple; (6) Lego; (7) Volkswagen; (8) Intel; (9) Rolex; (10) Daimler.
} 
literature. To the best of our knowledge, few exceptions are three recent articles: Goering (2007); Kopel and Brand (2012); Manasakis et al. (2014).

Goering (2007) investigates a mixed duopoly setting in which a private non-profit CSR firm competes with a private profit-maximising company. The stakeholders of the CSR firm select a contract for their managers. The author focuses on the Stackelberg competition mode, in which the non-profit firm is the market leader and he shows that, in subgame perfect equilibria, the managers of the leading company generally will not be given the true objective function to optimise.

Manasakis et al. (2014) study the incentives of firms' owners to commit voluntarily to CSR activities in oligopoly. Their approach is slightly different because the socially responsible attributes are attached to products, with consumers forming expectations about their existence and level. In other words, those authors consider the "demand-side" (the consumers') CSR preferences, while the abovementioned works mainly focuses on the "supply-side" (the firms') CSR preferences, in the sense that firms choose the quantity to supply to maximise also consumers' interests. The key result is that hiring an "individually" socially responsible manager and delegating to him the CSR effort and market decisions represents a commitment device for the firm's owners and credibly signals to consumers that the firm will undertake CSR activities.

Differently from the two above-mentioned papers, Kopel and Brand (2012) investigate, similarly to the current paper, the "strategic" role played by CSR (measured by the interest for consumer's surplus by shareholders) in a gametheoretic context in the frame of the Cournot model. ${ }^{5}$

Similar to Goering (2007), those authors analyse a mixed quantity-setting duopoly in which a socially concerned firm competes with a profit-maximising firm. Both firms may opt to hire a manager who determines the output to produce on behalf of the firm's owner. To hire a manager and delegate the output choice emerges as subgame perfect equilibrium for both firms. In the case of similar cost of production, the CSR firm has both a higher market share and profit. The relationship between the share of consumer surplus the CSR firm takes into account and its profit is non-monotonic: in fact, as the share increases, the CSR firm's profit first increases and then decreases.

However, all those contributions assume that stakeholders may decide also on manager's contracts and, in any case, they do not study an endogenously determined equilibrium in a duopoly with both CSR firms. ${ }^{6}$ Hence, this paper aims to fill this gap.

Although numerous articles have explored the empirical relationship between CSR performance and profitability performance, their results have often been contradictory (even within a given analysis) and, thus, no definitive consensus

\footnotetext{
5 To the best of the authors' knowledge Kopel and Brand (2012) is the unique paper dealing with the strategical analysis.

${ }^{6}$ Moreover, it is important to note that in these papers (i.e., Goering 2007; Kopel and Brand 2012) CSR may be strategically used unilaterally by one firm in order to increase rivals' costs when rivals are only profit-seeking, but if all the firms follow CSR rules profits are reduced.
} 
exists. For instance (1), most researchers have found only a negative relationship (see, inter alias, Bromiley and Marcus 1989; Davidson et al. 1987; Davidson and Worrel 1988); (2) some others have found an inconclusive relationship (e.g. Aupperle et al. 1985; Ingram and Frazier 1983); and (3) however, there is also an increasing number of articles showing a positive correlation between the social responsibility and financial performance of corporations (e.g. Griffin and Mahon 1997; Roman et al. 1999; Waddock and Graves 1997).

It is shown that under managerial delegation, the subgame perfect Nash equilibrium (SPNE) implies that both firms follow CSR rules, and the firms' profitability is always enhanced by their sensitivity to consumer surplus. This means that, if managers are delegated to select the optimal output following CSR rules, then the choice of firms to be CSR is due to economic convenience instead of altruistic behaviour. ${ }^{7}$ On the other hand, such a choice results to be welfare damaging, despite it aims to protect the consumers' interests. These results contrast the conventional wisdom.

The theoretical and empirical implications are rather intriguing. As regards the former implication, we recall that these unconventional results are obtained in a standard model in which owners instruct their managers to maximise not only the short-term profits (i.e. the shareholder value) but also the consumer's surplus. As regards the latter implication, we note that our model may provide the theoretical basis, rather unexpectedly, also within the "instrumental theory" of CSR for explaining some of the empirical findings showing a positive correlation between CSR performances and profitability performances.

Therefore, these findings may be important for the current policy debate on firms' social concern, in particular as regards social welfare as well as the motivation for the firm's owner to take into account the objectives of the stakeholders of his own firm.

The rest of this paper is structured as follows. Section 2 introduces the model setup, and Sect. 3, after having determined the SPNE in which both firms follows CSR rules, summarises the results. The last section concludes our findings.

\section{The model}

We assume the following standard linear inverse market demand

$$
p=a-q_{i}-q_{j}
$$

where $p$ denotes price, and $q_{i}$ and $q_{j}$ are the firms' output levels for $i, j=1,2$ and $i \neq j$. For tractability, both firms are assumed to have zero production costs.

Following the recent established literature (e.g. Goering 2007, 2008; Lambertini and Tampieri 2010), in the current model, we interpret the social concerns as part of consumer surplus: the feature of a CSR firm is to be sensitive to it. Consequently, we suppose that the firm wishes to maximise profits plus a fraction $k$ of the market

\footnotetext{
7 As regards the empirical relevance of this finding, we note that Fernández-Kranz and Santaló (2010) investigate the link between competition and firms' social performance to verify empirically whether CSR may be also driven by strategic considerations.
} 
consumer surplus in its objective. It follows that the participation of the stakeholders in governance applies on market choices: once involved in the firm's governance, they set the "social responsibility" level. Thus, the private owners of the socially responsible firms take as exogenously given the level of "social concern", $k$, given, for instance, by the "customary toughness" of the stakeholders incorporated in the firm's objective function. This is coherent with the results of the empirical study of Spitzeck and Hansen (2010), who find that the stakeholder engagement mechanism is mainly confined to "dialogue and issues" advisory, while the "structural" strategic choices (i.e. different from the output choices) of the company are outside their sphere. Furthermore, because firms compete for the same clients in the industry, it can be soundly assumed that stakeholders may ask both companies for an identical level of "social concern". ${ }^{8}$ As a consequence, the CSR firm's objective function may be specified as a simple parameterised combination of profits-which are given by $\pi_{i}=\left(a-q_{i}-q_{j}\right) q_{i}$-and consumer surplus.

Thus, the CSR objective function $(W)$ is:

$$
W_{i}=\pi_{i}+k \mathrm{CS}=\left(a-q_{i}-q_{j}\right) q_{i}+k \frac{\left(q_{i}+q_{j}\right)^{2}}{2}
$$

where $k \in[0 ; 1]$ denotes the weight that CSR firms assign to consumer surplus. ${ }^{9}$

\subsection{The benchmark model}

In this case, the firms follow CSR rules; however, they are not managerial. The analysis is carried out as usual through the maximisation of (2) with respect to the quantity and solving the system of the two reaction functions

$$
q_{i}\left(q_{j}\right)=\frac{a-q_{j}(1-k)}{2-k}
$$

for $i, j=1,2$ and $i \neq j$, one gets the equilibrium output

$$
q^{\mathrm{CSR} / \mathrm{CSR}}=\frac{a}{3-2 k}
$$

Substituting (3) backwards, we obtain the equilibrium profits and consumer surplus, respectively

$$
\pi^{\mathrm{CSR} / \mathrm{CSR}}=\frac{a^{2}(1-2 k)}{(3-2 k)^{2}}
$$

\footnotetext{
8 Alternatively, it can be hypothesised that the firms' choice of the level of "social concern" is endogenous, that is, the level of $k$ is entirely under the control of the firms' owners and does not depend on the stakeholders. This alternative view is investigated in the 'Appendix'.

9 Commercial Non-profit organizations (NPOs) selling their output and services, which provide them revenue, may be also considered CSR firms. Indeed, Goering $(2007,2008)$ characterises this objective function also to the NPOs which compete in commercial markets, for instance in industries such that University bookstores (Schiff and Weisbrod 1991), water utility, rail track maintenance company, private air-traffic control organization (Bennett et al. 2003) and even in the high-tech markets (Benz 2005).
} 


$$
\mathrm{CS}^{\mathrm{CSR} / \mathrm{CSR}}=2\left(\frac{a}{3-2 k}\right)^{2}
$$

where the superscript CSR denotes that firms are socially concerned. Note that the satisfaction of the non-negativity constraints on profits requires ultimately that $k \leq 1 / 2$, that is, the firm's interest for the consumer's welfare has not to be too high. This inequality also holds true for the rest of the paper.

\subsection{The model with managerial firms}

We introduce managerial delegation in the usual way, by assuming that the owners of both firms hire a manager and delegate the output decision to this manager. ${ }^{10}$ Each manager receives a fixed salary plus a bonus element, which is related to a weighted combination between firms' profits and sales. Moreover, we also follow the standard assumption by managerial delegation theory that the fixed component (salary) of the manager pay is chosen by the firm's owner such that the manager exactly gets his/her opportunity cost, which is normalised to zero. More specifically, following for instance Vickers (1985), Jansen et al. (2007, 2009), Fanti and Meccheri (2013), Meccheri and Fanti (2014), manager $i$ receives a bonus that is proportional to

$$
u_{i}=W_{i}+b_{i} q_{i},
$$

where the weight $b_{i}$ is chosen by the owner $i$ to maximise its own objective function, and it can be either positive or negative because the owner may provide incentives or disincentives to the manager's choice of output (sales).

The timing of the game is usually as follows. At stage 1, every firm's owner decides the weight on sales in the manager's bonus formula. At stage 2, each manager competes in quantities. The equilibrium concept considered is the SPNE, obtained solving the model by backward induction.

Given the CSR firm's objective function (2), $u_{i}$ (which drives the manager $i$ 's utility) can be rewritten as:

$$
u_{i}=\left(a-q_{i}-q_{j}\right) q_{i}+k \frac{\left(q_{i}+q_{j}\right)^{2}}{2}+b_{i} q_{i} .
$$

Hence, the equilibrium of the second stage of the game (the market game) must satisfy:

$$
\frac{\partial u_{i}}{\partial q_{i}}=0
$$

for $i, j=1,2$ and $i \neq j$. From (9), we obtain the reaction functions

\footnotetext{
${ }^{10}$ Note that it can be shown that the decision of both firms of CSR-type to hire a manager is a SPNE of a standard managerial delegation game in which each firm chooses whether to hire a manager. However the analysis of such a game is beyond the scope of this paper.
} 


$$
q_{i}\left(q_{j}, b_{i}\right)=\frac{a+b_{i}-q_{j}(1-k)}{2-k}
$$

After the usual calculations, one gets the equilibrium output and profits as a function of the weights on quantities of the manager's bonus scheme:

$$
\begin{gathered}
q_{i}\left(b_{j}, b_{i}\right)=\frac{a+b_{i}(2-k)-b_{j}(1-k)}{3-2 k} \\
\pi_{i}\left(b_{j}, b_{i}\right)=\frac{\left[a+b_{i}(2-k)-b_{j}(1-k)\right]\left[a(1-2 k)-b_{j}-b_{i}\right]}{(3-2 k)^{2}}
\end{gathered}
$$

Maximising profits with respect to $b_{i}$ and then solving the system of the following reaction functions in bonuses space

$$
b_{i}\left(b_{j}\right)=\frac{a\left(1-5 k+2 k^{2}\right)-b_{j}}{2(2-k)}
$$

One gets the following (symmetric) equilibrium value for $b$ :

$$
b_{i}=b_{j}=b=\frac{a\left(1-5 k+2 k^{2}\right)}{5-2 k}
$$

with $\partial b_{i} / \partial k<0$ : CSR has a mitigating effect on the manager's bonus.

Lemma 1 The weight on quantities is positive (resp. negative) when the sensitivity to consumer surplus is low (resp. high).

Proof

$$
b \frac{>}{<}=0 \Leftarrow k \frac{<}{>} k^{\circ}=0.219
$$

The received literature argues that it is optimal for firms' owners to twist their manager's incentives away from strict profit maximisation towards sales incentives. Lemma 1 reveals that, in this model, this occurs only if the social concern of the firm is sufficiently low; otherwise, it is optimal for owners to twist their manager's incentives away from sales.

Substituting backwards the equilibrium weight on quantities, one gets the subperfect equilibrium output, profit and consumer surplus in the delegation case, respectively

$$
\begin{aligned}
q^{\mathrm{D}, \mathrm{CSR} / \mathrm{CSR}} & =\frac{a(2-k)}{5-2 k} \\
\pi^{\mathrm{D}, \mathrm{CSR} / \mathrm{CSR}} & =\frac{a^{2}(2-k)}{(5-2 k)^{2}}
\end{aligned}
$$




$$
C S^{\mathrm{D}, \mathrm{CSR} / \mathrm{CSR}}=2\left(\frac{a(2-k)}{5-2 k}\right)^{2}
$$

where the first superscript, D, denotes "managerial delegation", and the second that the firms follow CSR rules. Observing that when $k=0$ firms simply maximise profits, the duopoly outcomes in the standard profit-maximisation case become

$$
\begin{gathered}
q^{\mathrm{D}, \mathrm{PS} / \mathrm{PS}}=\frac{2 a}{5} \\
\pi^{\mathrm{D}, \mathrm{PS} / \mathrm{PS}}=2\left(\frac{a}{5}\right)^{2} \\
C S^{\mathrm{D}, \mathrm{PS} / \mathrm{PS}}=8\left(\frac{a}{5}\right)^{2}
\end{gathered}
$$

where the superscript PS stands for "profit-seeking" firms.

\section{Results}

The above results report the equilibrium outcomes under exogenously given situations of only profit-seeking managers and socially concerned managers.

Now we extend the above analysis by letting the firm endogenously choose whether to instruct its manager to follow CSR rules. We show that the endogenous decisions of following CSR rules emerge as the SPNE outcome.

\subsection{The mixed case: one manager follows CSR rules and the other one is profit-seeking}

Let us consider the case that the firm $i$ 's manager maximises the social objective function, while the rival $j$ 's manager maximises profits.

In the second stage, the firm i's maximises (8) with respect to the quantity. Solving for $q_{i}$ the system of the FOCs, we derive

$$
q_{i}\left(q_{j}\right)=\frac{a+b_{i}-q_{j}(1-k)}{2-k}
$$

which represents firm $i$ 's output as function of the rival firm's output. On the other hand, firm $j$ 's manager maximises the following utility function:

$$
u_{j}^{\mathrm{PS}}=\left(a-q_{i}-q_{j}\right) q_{j}+b_{j} q_{j} .
$$

From (19), the FOCs for firm $j$ determine the following reaction function 


$$
q_{j}\left(q_{i}\right)=\frac{a+b_{j}-q_{i}}{2}
$$

Solving the system composed by (18) and (20) for the firms' quantities, we obtain

$$
q_{i}=\frac{a(1+k)+2 b_{i}-b_{j}(1-k)}{3-k}
$$

the firm's $i$ output and

$$
q_{j}=\frac{a(1-k)+b_{j}(2-k)-b_{i}}{3-k}
$$

the firm's $j$ optimal response. Both response functions are expressed as function both of its and the rival firm's bonus weights.

In the first stage of the game, firm $j$ 's owner maximises with respect its manager's bonus weight the following [after inserting (21) and (22) in the profit function]:

$$
\pi_{i}\left(b_{i}, b_{j}\right)=\frac{\left[a(1+k)+2 b_{i}-b_{j}(1-k)\right]\left[a(1-k)-b_{i}-b_{j}\right]}{(3-k)^{2}}
$$

Solving with respect to $b_{i}$ leads to the following reaction function for the owner $i$ :

$$
b_{i}\left(b_{j}\right)=\frac{a(1-3 k)-b_{j}(1+k)}{4}
$$

Likewise, firm $j$ 's owner maximises the following

$$
\pi_{j}\left(b_{i}, b_{j}\right)=\frac{\left[a(1-k)-b_{i}+b_{j}(2-k)\right]\left[a(1-k)-b_{i}-b_{j}\right]}{(3-k)^{2}} .
$$

Solving with respect to $b_{j}$ leads to the following reaction function for the owner $j$ :

$$
b_{j}\left(b_{i}\right)=\frac{(1-k)\left[a(1-k)-b_{i}\right]}{2(2-k)} .
$$

In the asymmetric equilibrium of the first stage subgame, we obtain

$$
\begin{gathered}
b_{i}=\frac{a\left(1+k^{2}-4 k\right)}{5-k} \\
b_{j}=\frac{a(1-k)}{5-k}
\end{gathered}
$$

Note that under CSR rules, the owner may fix even a negative bonus when its social concerns are relatively high. More precisely, $b_{i}>0 \Leftarrow k \frac{<}{>} k^{\circ \circ}=0.267$. In other words, the CSR firm's owner will twist their manager's incentives towards (away from) sales depending on whether they are strongly (weakly) social concerns oriented. 
By substituting (27) and (28) in (21)-(23) and (25), we find the following equilibrium outcomes of the mixed case:

$$
\begin{aligned}
q_{i}^{\mathrm{D}, \mathrm{CSR} / \mathrm{PS}} & =\frac{2 a}{5-k} \\
q_{j}^{\mathrm{D}, \mathrm{CSR} / \mathrm{PS}} & =\frac{a(2-k)}{5-k} \\
\pi_{i}^{\mathrm{D}, \mathrm{CSR} / \mathrm{PS}} & =\frac{2 a^{2}}{(5-k)^{2}} \\
\pi_{j}^{\mathrm{D}, \mathrm{CSR} / \mathrm{PS}} & =\frac{a^{2}(2-k)}{(5-k)^{2}}
\end{aligned}
$$

\subsection{Equilibrium analysis}

Now we are in a position to conduct the following analysis. We compare firm's profits under the two mixed cases, and we investigate which rule (CSR or profitseeking) endogenously emerges as SPNE for both firms in the presence of managerial delegation. Let us define the following profits differentials: $\Delta \pi_{1}=$ $\pi_{i}^{\mathrm{CSR} / \mathrm{PS}}-\pi^{\mathrm{PS} / \mathrm{PS}}$ and $\Delta \pi_{2}=\pi_{j}^{\mathrm{CSR} / \mathrm{PS}}-\pi^{\mathrm{CSR} / \mathrm{CSR}}$. Hence, we state the following:

Result 1 In the SPNE outcome of the game both firms choose to instruct their managers to follow CSR rules.

Proof Result 1 straightforwardly derives from the signs of the two profit differentials involved in the determination of the SPNE:

1.

$$
\Delta \pi_{1}=\pi_{i}^{\mathrm{D}, \mathrm{CSR} / \mathrm{PS}}-\pi^{\mathrm{D}, \mathrm{PS} / \mathrm{PS}}=\frac{2 a^{2} k(10-k)}{25(5-k)^{2}}>0
$$

2.

$$
\Delta \pi_{2}=\pi_{j}^{\mathrm{D}, \mathrm{CSR} / \mathrm{PS}}-\pi^{\mathrm{D}, \mathrm{CSR} / \mathrm{CSR}}=\frac{a^{2} k(3 k-10)(2-k)}{(2 k-5)^{2}(5-k)^{2}}<0 .
$$

Now, having established that both firms endogenously choose to be CSR-type, we investigate how profits and welfare vary with the importance of the CSR motive in the cases without and with managerial delegation. Then, the following results hold: ${ }^{11}$

\footnotetext{
11 Note that these results are also robust to the introduction of differentiated products. For economy of space the model with product differentiation is not presented here and is disposable on request.
} 
Result 2 (a) As expected, under the standard profit-maximising behaviour, the higher $k$ is the lower profit is; (b) in contrast to the common wisdom, under managerial delegation the higher $k$ is the higher profit is.

Proof recalling that $k \leq 1 / 2$, this straightforwardly follows from $\frac{\partial \pi^{\mathrm{CSR} / \mathrm{CSR}}}{\partial k}=$ $\frac{2 a^{2}(2 k+1)}{(2 k-3)^{3}}<0$ and $\frac{\partial \pi^{\mathrm{D}, \mathrm{CSR} / \mathrm{CSR}}}{\partial k}=\frac{a^{2}(2 k-3)}{(2 k-5)^{3}}>0$.

Result 3 (a) As expected, under the standard profit-maximising behaviour without managerial delegation, the higher $k$ is, the higher consumer surplus ${ }^{12}$ is; $(b)$ in contrast to the common wisdom, under managerial delegation, the higher $k$ is the lower consumer surplus is.

Proof Recalling that $k \leq 1 / 2$, this straightforwardly follows from $\frac{\partial \mathrm{CS} \operatorname{CSR} / \mathrm{CSR}}{\partial k}=$ $\frac{8 a^{2}}{(3-2 k)^{3}}>0$ and $\frac{\partial \mathrm{CS}^{\mathrm{D}, \mathrm{CSR} / \mathrm{CSR}}}{\partial k}=-\frac{4 a^{2}(k-2)}{(2 k-5)^{3}}<0$.

Hence, when firms are managerial, as a modern theory of corporation governance argues, an increase in their "social concern" with respect to the decisions on output may, rather counter-intuitively, actually decrease consumer surplus and increase firms' profitability.

The explanation for this result is as follows. There are two opposite forces at work. On the one hand, the introduction of CSR and the increasing weight attached to the stakeholder-consumers" interests lead the firms to a "more aggressive" market behaviour through output expansion (Fanti and Buccella 2016). On the other hand, with managerial firms, CSR softens the magnitude of the manager's bonus on sales in equilibrium. Result 3 tells us that with managerial firms, the second effect of CSR dominates, leading to a reduction in output and, consequently, to a rise in prices and profitability. Moreover, this has also a negative effect on social welfare, given its direct correlation with consumer surplus. In fact, the value of the consumers surplus in the social welfare function always dominates that of profits (a well-known result in the IO literature in the presence of standard linear demand and technology). Therefore, in the presence of managerial delegation, the negative effect of the "social concern" on consumers' welfare overcomes the positive effect on profits, and thus the social welfare reaches a minimum (compatible) with the non-negativity constraint condition of profits. These results imply that an analysis of the impact of firms' social concern should take into account the market context and the strategic behaviours of the CSR firms as well as the separation between control and ownership as regards the decisions on quantity competition.

\footnotetext{
12 Note that in this type of models the final effect on the social welfare as a whole which is defined as the sum of firms' profits and consumer surplus is always qualitatively the same of that on the consumer's surplus.
} 


\section{Conclusions}

The paper shows that in a Cournot duopoly with managerial firms both firms obtain higher profits adopting CSR rules in the product market game (i.e. to be sensitive to consumer surplus), and the firms' profitability is always increasing with their social concern. Conversely, the work shows that consumer surplus and social welfare are reduced when firms adopt CSR rules, and the higher the firms' social concern, the lower the consumers' and social welfares. This finding is in sharp contrast with the conventional result (established with non-managerial firms) that the higher the CSR sensitivity to consumer surplus, the lower (resp. higher) the firms' profitability (resp. the consumer surplus and social welfare). ${ }^{13}$

Moreover, importantly, the firms' type (either CSR or profit-seeking) has been endogenously determined in an appropriate game context, showing that in the SPNE of the game, both firms are of CSR-type.

The implication of our findings is striking: the choice to follow CSR rules in the production's choice stage (which is also robust because endogenously determined) is not related to social interests, but it is moved by profit-enhancing reasons. On the other hand, consumers and society should, rather paradoxically, hinder firms' social concerns. While in the owner-managed firm it is never profitable to take into account the consumer surplus in the firm's objective, in the managerial firm profits are higher when owners instruct their managers to take into account the consumer surplus in their objective, and in particular, if owners may choose also "how much" to consider the consumer surplus, then a profit-maximising level of CSR does always exist (for details, see the "Appendix"). Therefore, the present work revisits the reasoning of Friedman (1970) in a context of separation between management and ownership showing that owners can find beneficial to delegate to managers engaged in CSR activities to improve the firms' profitability.

Several extensions of the present simple model come to mind. Among others, we mention: (1) to assume price competition; (2) to assume a different structure of the manager's incentive contract, such as contracts related to the relative firms' profitability or market shares; (3) to assume that products are horizontally and vertically differentiated; (4) to consider consumption externalities; (5) to consider an endogenous timing of moves of the game; and (6) to consider the presence of asymmetric and endogenous costs (such as unionised labour costs). These extensions are left for further research.

Acknowledgements We are extremely grateful to the two anonymous referees for comments and suggestions that have substantially improved the quality and clarity of this paper. The usual disclaimers apply.

Funding This study was not funded by any Institution.

\footnotetext{
${ }^{13}$ However, this result appears to meet the feelings of the participants in a debate organised by the Economist Intelligence Unit (2013): 75\% of the contributors expressed the opinion that CSR gives companies a competitive advantage, and responsibility is a real business issue.
} 


\section{Compliance with ethical standards}

Conflict of interest The authors declare that they have no conflict of interest.

Open Access This article is distributed under the terms of the Creative Commons Attribution 4.0 International License (http://creativecommons.org/licenses/by/4.0/), which permits unrestricted use, distribution, and reproduction in any medium, provided you give appropriate credit to the original author(s) and the source, provide a link to the Creative Commons license, and indicate if changes were made.

\section{Appendix}

\section{Owners choose the level of the weight $k$}

In the main text the level of the weight $k$ is exogenously given from the general economic environment or context in which firms operate. In addition, following the established literature, we have assumed that $k \in[0 ; 1]$. In this "Appendix", we relax those assumptions. Let us suppose that: (1) owners have the power to choose the level of the weight attributed to the consumer surplus in the objective function and (2) $k>0$. In this case, there is an initial stage of the game in which owners choose $k$ to maximise their profits. This amounts to maximise Eq. (16) with respect to $k .^{14}$

Result 4 Profits are maximised for $k=k^{\max }=1.5$.

Proof Observing that from Eq. (16) $k \leq 2$, this straightforwardly follows from $\frac{\partial \pi^{\mathrm{D}}}{\partial k}=\frac{a^{2}(2 k-3)}{(2 k-5)^{3}}=0 \Leftrightarrow k=k^{\mathrm{max}}=1.5$.

The economic consequences of this result are intriguing: when firms are managerial, shareholders have convenience not only to take into account the consumer surplus but to attribute it a weight larger than that of profits in the firm's objective function.

Now we show another intriguing result. As known, a tenet of the managerial delegation literature is that at equilibrium the managerial firm is less profitable than a profit-seeking firm (i.e. directly managed by owners) (e.g. Fershtman and Judd 1987). As a consequence, one might think that owners may always obtain a higher profits if they do not delegate to managers and have not social concerns. However, this belief is erroneous: under managerial delegation profits may be higher than without delegation provided that owners attribute a sufficiently large (but not too large) weight to the consumer surplus, as the following result states.

\footnotetext{
14 This corresponds to a cooperative choice of an optimal level of CSR by both firms. We note that in this model with managerial delegation a non-cooperative choice of an optimal $k$ by owners would not be feasible (while such a choice would lead to a common optimal value of $k=0.219$ in the case of profitseeking - i.e. without delegation-firms, where, however, by contrast, a cooperative optimal choice of $k$ would be not feasible). These arguments are treated in a companion paper where firms compete in the absence of managerial delegation.
} 
Result 5 Profits under managerial delegation are larger than those under no delegation when in the former case owners confers to the consumer surplus a weight in the firms' objective function equal to $1<k<1.75$ and in the latter case set $k=0$.

Proof Given that, from Eq. 5, it is easy to see that profits are maximal when $k=0$, Result 5 straightforwardly follows by showing that $\left(\pi^{\mathrm{D}, \mathrm{CSR} / \mathrm{CSR}}-\pi_{\mid k=0}\right)$ $=\frac{a^{2}(1-k)(4 k-7)}{9(2 k-5)^{2}}>0 \Leftrightarrow 1<k<1.75$.

Result 5 implies that in the case in which owners may choose whether and how to be socially responsible, the common wisdom that managerial delegation is profit reducing at equilibrium is reversed (even for a wide range of the weight $k$ ).

More interestingly, Results 4 and 5 jointly indicate, in contrast to the common wisdom, the unexpected result that at the market equilibrium shareholders find more profitable to delegate to managers and be strongly socially responsible (in the sense that they confer more importance to the welfare of the consumer than their own profits). The economic intuition of this result is grounded on the role played by the sales incentive's value in the managerial contract. In fact, given that the consumer surplus has a substantial incidence in the objective function, the owners strategically use quantities via the adoption of the CSR and then, through the bonus, they may penalise managers with respect to output (however, not always, depending on the opportunely weighted level of social engagement) to increase the firms' profitability.

\section{References}

Aupperle KE, Carroll AB, Hatfield JD (1985) An empirical examination of the relationship between corporate social responsibility and profitability. Acad Manag J 28(2):446-463

Baron D (2001) Private politics, corporate social responsibility, and integrated strategy. J Econ Manag Strategy 10:7-45

Baron DP (2009) A positive theory of moral management, social pressure, and corporate social performance. J Econ Manag Strategy 18:7-43

Benabou R, Tirole J (2010) Individual and corporate social responsibility. Economica 77:1-19

Bennett J, Iossa E, Legrenzi G (2003) The role of commercial non-profit organizations in the provision of public services. Oxford Rev Econ Policy 19:335-347

Benz M (2005) Not for profit, but for satisfaction? Evidence on worker well-being in non-profit firms. Kyklos 58:155-176

Bromiley P, Marcus A (1989) The deterrent to dubious corporate behavior: profitability, probability and safety recalls. Strateg Manag J 10(3):233-250

Chong WN, Tan G (2010) Obtaining intangible and tangible benefits from corporate social responsibility. Int Rev Bus Res Pap 6(4):360-371

Davidson WN, Worrel DL (1988) The impact of announcements of corporate illegalities on shareholder returns. Acad Manag J 31(1):195-200

Davidson WN, Chandy PR, Cross M (1987) Large losses, risk management and stock returns in the airline industry. J Risk Insur 54(1):162-172

European Commission (2001) Promoting a European framework for corporate social responsibility. Green Paper, Office for Official Publications of the European Communities, Luxembourg

Fanti L, Buccella D (2016) Corporate social responsibility in a game-theoretic context. Economia e Politica Industriale. doi:10.1007/s40812-016-0064-3

Fanti L, Meccheri N (2013) Managerial delegation under alternative unionization structures. Labour 27:38-57 
Fernández-Kranz D, Santaló J (2010) When necessity becomes a virtue: the effect of product market competition on corporate social responsibility. J Econ Manag Strategy 19:453-487

Fershtman C, Judd K (1987) Equilibrium incentives in oligopoly. Am Econ Rev 77:927-940

Forbes (2014) The companies with the best CSR reputations. http://www.forbes.com/sites/kathryndill/ 2014/12/08/the-companies-with-the-best-csr-reputations/. 8 Dec 2014

Frank R (2003) What price the moral high ground? Ethical dilemmas in competitive environments. Princeton University Press, Princeton

Friedman M (1970) The social responsibility of business is to increase its profits. In: New York Times Magazine, September 13th, 32-33, 122-126

García-Gallego A, Georgantzís N (2009) Market effects of changes in consumers' social responsibility. J Econ Manag Strategy 18(1):235-262

Garriga E, Melè D (2004) Corporate social responsibility theories: mapping the territory. J Bus Ethics 53:51-71

Goering GE (2007) The strategic use of managerial incentives in a non-profit firm mixed duopoly. Manag Decis Econ 28:83-91

Goering GE (2008) Welfare impacts of a non-profit firm in mixed commercial markets. Econ Syst 32:326-334

Griffin JJ, Mahon JF (1997) The corporate social performance and corporate financial performance debate twenty-five years of incomparable research. Bus Soc 36(1):5-31

Ingram RW, Frazier KB (1983) Narrative disclosures in annual reports. J Bus Res 11(1):49-60

Jansen T, van Lier A, van Witteloostuijn A (2007) A note on strategic delegation: the market share case. Int J Ind Organ 25:531-539

Jansen T, van Lier A, van Witteloostuijn A (2009) On the impact of managerial bonus systems on firm profit and market competition: the cases of pure profit, sales, market share and relative profits compared. Manag Decis Econ 30:141-153

Jensen MC (2000) Value maximization, stakeholder theory, and the corporate objective function. In: Beer M, Nohria N (eds) Breaking the code of change. Harvard Business School Press, Boston, pp 37-58. Reprinted (2002) as Value maximization, stakeholder theory, and the corporate objective function, Business ethics quarterly 12(2), 235-256

Jensen MC (2001) Value maximization, stakeholder theory, and the corporate objective function. J Appl Corp Finance 14(3):8-21

Kopel M, Brand B (2012) Socially responsible firms and endogenous choice of strategic incentives. Econ Model 29:982-989

KPMG (2013) KPMG survey of corporate responsibility reporting 2013. https://assets.kpmg.com/content/ dam/kpmg/pdf/2015/08/kpmg-survey-of-corporate-responsibility-reporting-2013.pdf

Lambertini L, Tampieri A (2010) Corporate social responsibility in a mixed oligopoly. Department of Economics, University of Bologna, working paper 723

Manasakis C, Mitrokostas E, Petrakis E (2014) Strategic corporate social responsibility activities and corporate governance in imperfectly competitive markets. Manag Decis Econ 35:460-473

Meccheri N, Fanti L (2014) Managerial delegation contracts under centralized unionization. Manag Decis Econ 35:51-66

Reinhardt FL, Stavins RN (2010) Corporate social responsibility, business strategy, and the environment. Oxford Rev Econ Policy 26(2):164-181

Reputation Institute, 2014. 2014 Global CSR RepTrak 100. Available online at http://www. reputationinstitute.com/thought-leadership/complimentary-reports-2014

Roman RM, Hayibor S, Agle BR (1999) The relationship between social and financial performance repainting a portrait. Bus Soc 38(1):109-125

Schiff J, Weisbrod B (1991) Competition between for-profit and non-profit organizations in commercial markets. Ann Public Coop Econ 62:619-639

Spitzeck H, Hansen EG (2010) Stakeholder governance: how stakeholders influence corporate decision making. Corp Gov Int J Bus Soc 10(4):378-391

The Economist Intelligence Unit (2013) The Corporations and Communities Debate Series: "CSR has nothing to do with charity." March 4th-March 15th 2013. A summary paper from the Economist Intelligence Unit

Vickers J (1985) Delegation and the theory of the firm. Econ J 95:138-147

Waddock SA, Graves SB (1997) The corporate social performance-financial performance link. Strateg Manag J 18(4):303-319 